Technological University Dublin

ARROW@TU Dublin

\title{
UV and Visible Light Activated TiO2 Photocatalysis of 6-Hydroxymethyluracil, a Model Compound for the Potent Cyanotoxin Cylindrospermopsin
}

\author{
Cen Zhao \\ Florida International University \\ Miquel Pelaez \\ University of Cincinnati, \\ Dionysios Dionysiou \\ University of Cincinnati,
}

See next page for additional authors

Follow this and additional works at: https://arrow.tudublin.ie/cenresart

Part of the Chemistry Commons

\section{Recommended Citation}

Zhao, C. et al. (2013) UV and visible light activated TiO2 photocatalysis of 6-hydroxymethyluracil, a model compound for the potent cyanotoxin cylindrospermopsin. Catalysis Today, Vol. 224, April 2014. Available online October, 2013. doi:10.1016/j.cattod.2013.09.042

This Article is brought to you for free and open access by the Crest: Centre for Research in Engineering Surface Technology at ARROW@TU Dublin. It has been accepted for inclusion in Articles by an authorized administrator of ARROW@TU Dublin. For more information, please contact arrow.admin@tudublin.ie, aisling.coyne@tudublin.ie,gerard.connolly@tudublin.ie.

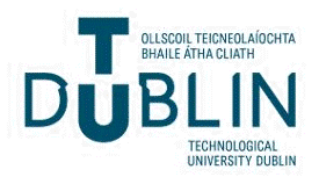


Authors

Cen Zhao, Miquel Pelaez, Dionysios Dionysiou, Suresh Pillai, John Byrne, and Kevin O'Shea

This article is available at ARROW@TU Dublin: https://arrow.tudublin.ie/cenresart/42 


\title{
UV and visible light activated $\mathrm{TiO}_{2}$ photocatalysis of 6-hydroxymethyl uracil, a model compound for the potent cyanotoxin cylindrospermopsin
}

\author{
Cen Zhao ${ }^{a}$, Miguel Pelaez ${ }^{\mathrm{b}}$, Dionysios D. Dionysiou ${ }^{\mathrm{b}}$, Suresh C. Pillai ${ }^{\mathrm{c}}$, \\ John A. Byrne ${ }^{\mathrm{d}}$, Kevin E. O'Shea ${ }^{\mathrm{a}, *}$ \\ a Department of Chemistry and Biochemistry, Florida International University, Miami, FL 33199, USA \\ ${ }^{\mathrm{b}}$ Environmental Engineering and Science Program, University of Cincinnati, Cincinnati, OH 45221-0012, USA \\ c Centre for Research in Engineering Surface Technology (CREST), Focas Institute, Dublin Institute of Technology, Kevin Street, Dublin 8, Ireland \\ ${ }^{\mathrm{d}}$ Nanotechnology Integrated Bio-Engineering Centre, University of Ulster, Newtownabbey, Northern Ireland BT37 OQB, UK
}

\section{A R T I C L E I N F O}

\section{Article history:}

Received 2 August 2013

Received in revised form

11 September 2013

Accepted 22 September 2013

Available online $\mathrm{xxx}$

\section{Keywords:}

Cylindrospermopsin (CYN)

6-Hydroxymethyl uracil (6-HOMU)

$\mathrm{NF}-\mathrm{TiO}_{2}$

Photocatalysis

Visible light

\begin{abstract}
A B S T R A C T
$\mathrm{TiO}_{2}$ photocatalyses of 6-hydroxymethyl uracil (6-HOMU) a model compound for the potent cyanotoxin, cylindrospermopsin (CYN), were carried out employing visible and UV irradiation using different non-metal doped $\mathrm{TiO}_{2}$ materials, nitrogen and fluorine- $\mathrm{TiO}_{2}\left(\mathrm{NF}-\mathrm{TiO}_{2}\right)$, phosphorus and fluorine- $\mathrm{TiO}_{2}$ $\left(\mathrm{PF}-\mathrm{TiO}_{2}\right)$ and sulfur- $\mathrm{TiO}_{2}\left(\mathrm{~S}-\mathrm{TiO}_{2}\right)$. The model compound was readily degraded under $\mathrm{UV} \mathrm{TiO}_{2}$ photocata-

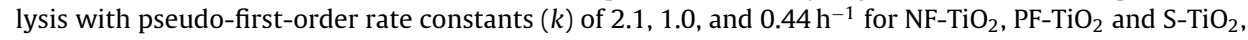
respectively. Under visible light activated (VLA), $\mathrm{NF}-\mathrm{TiO}_{2}$ was the most active photocatalyst, $\mathrm{PF}-\mathrm{TiO}_{2}$ was marginally active and $\mathrm{S}-\mathrm{TiO}_{2}$ inactive. VLA NF- $\mathrm{TiO}_{2}$ was effective and increased the $k$ with increasing $\mathrm{pH}$ from 3 to 9. The presence of humic acid (HA), $\mathrm{Fe}^{3+}$ and $\mathrm{Cu}^{2+}$ can enhance the degradation. However, at $20 \mathrm{ppm}$ HA significant inhibition was observed, likely due to shadowing of the catalyst, quenching of ROS or blocking active sites of $\mathrm{TiO}_{2}$. We probed the roles of different reactive oxygen species (ROS) using specific scavengers and the results indicate that $\mathrm{O}_{2}{ }^{\bullet-}$ plays an important role in $\mathrm{VLA} \mathrm{TiO}_{2}$ photocatalysis. Our results demonstrate that $\mathrm{NF}-\mathrm{TiO}_{2}$ photocatalysis is effective under UV and visible irradiation and over a range of water qualities. $\mathrm{VLA} \mathrm{NF}-\mathrm{TiO}_{2}$ photocatalysis is an attractive alternative technology for the CYN contaminated water treatment.
\end{abstract}

(c) 2013 Elsevier B.V. All rights reserved.

\section{Introduction}

Cyanobacteria commonly exist in drinking water sources and can lead to harmful algae blooms (HABs). Seventy percent of HABs can produce potent toxins $[1,2]$ and thus pose a tremendous risk to humans and the environment. One of the more problematic cyanotoxins is cylindrospermopsin (CYN), an alkaloid with a tricyclic guanidine group and uracil ring. CYN has been showed to be genotoxic [3,4] and carcinogenic [5]. The main target organs of CYN include the liver, kidney, thymus, lungs and adrenal glands. Human exposure to cylindrospermopsin occurs through ingestion of CYN contaminated food or water, or during recreational activities during HABs in lakes and fresh water systems. The most notable incident of CYN on human health occurred on Palm Island, Australia in 1979, which led to hepatoenteritis in 138 children and 10 adults [6]. Despite this notorious incident, CYN was not

\footnotetext{
* Corresponding author. Tel.: +1 305348 3968; fax: +1 3053483772 .

E-mail address: osheak@fiu.edu (K.E. O’Shea).
}

isolated and identified until 1992 [7]. CYN is also responsible for the poisoning of livestock [8].

The occurrences and volumes of toxic cyanobacterial blooms have increased significantly in recent years due to climate change and increasing eutrophication. With the increasing pressure and global need for clean water, it is desirable to identify a sustainable treatment process for the elimination of naturally occurring cyanotoxins from drinking water. Conventional water treatment methods such as coagulation, flocculation, sedimentation and filtration are often not viable for removing cyanotoxins $[9,10]$. Although activated carbon may be effective to remove cyanotoxins in the laboratory, treatments of large volumes of contaminated water are often not economically practical. The high levels of natural organic material (NOM) associated with HABs can have a pronounced negative impact on the effectiveness of the activated carbon process [11]. Chlorine and ozone based treatments have been studied for removal of cyanotoxins, however, by products like trihalomethanes (THMs) (by chlorination) and bromate (by ozonation) are a concern because of associated health consequences $[12,13]$. 


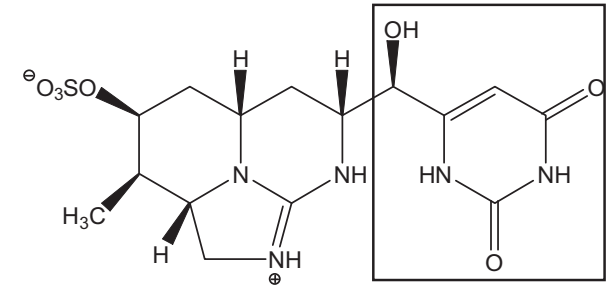<smiles>O=c1cc(CO)[nH]c(=O)[nH]1</smiles>

Fig. 1. Structure of cylindrospermopsin (CYN) and the model compound 6hydroxymethyl uracil (6-HOMU).

Advanced oxidation processes (AOPs) have received considerable attention for the treatment of water contaminated with a wide variety of toxins and pollutants. AOPs employ the hydroxyl radical $\left(\mathrm{HO}^{\bullet}\right)$ as the primary oxidant in the oxidative remediation of toxins in drinking water. $\mathrm{HO}^{\bullet}$ is a very powerful oxidant, which can react rapidly with nearly all organic compounds due to its strong oxidation potential $(+2.80 \mathrm{~V})$ [14]. $\mathrm{UV} \mathrm{TiO}_{2}$ photocatalysis is effective for the destruction of an extensive number of toxins and organic contaminants in the wastewater and drinking water $[15,16]$. Conventional $\mathrm{UV} \mathrm{TiO}_{2}$ photocatalysis can produce a number of reactive oxygen species (ROS), however $\mathrm{HO}^{\bullet}$ is generally associated with the effective destruction of organic compounds. UV photoexcitation of $\mathrm{TiO}_{2}$ produces electron/hole $\left(\mathrm{e}_{\mathrm{cb}}{ }^{-} / \mathrm{h}_{\mathrm{vb}}{ }^{+}\right)$pairs as illustrated by Eq. (1). The $\mathrm{e}_{\mathrm{cb}}{ }^{-}$can reduce molecular oxygen yielding superoxide anion radical $\left(\mathrm{O}_{2}{ }^{\bullet-}\right)$, Eq. (2) and the $\mathrm{h}_{\mathrm{vb}}{ }^{+}$has the potential to oxidize surface absorbed $\mathrm{H}_{2} \mathrm{O}$ or hydroxyl groups to generate $\mathrm{HO}^{\bullet}$, Eq. (3). Another source of $\mathrm{HO}^{\bullet}$ can occurs via disproportionation of $\mathrm{O}_{2}{ }^{\bullet-}$, yielding $\mathrm{H}_{2} \mathrm{O}_{2}$, Eq. (4), which can be reduced to HO• Eq. (5).

$\mathrm{TiO}_{2}+\mathrm{h} v \rightarrow \mathrm{e}_{\mathrm{cb}}{ }^{-}+\mathrm{h}_{\mathrm{vb}}{ }^{+}$

$\mathrm{e}_{\mathrm{cb}}{ }^{-}+\mathrm{O}_{2} \rightarrow \mathrm{O}_{2}{ }^{\bullet-}$

$\mathrm{h}_{\mathrm{vb}}{ }^{+}+\mathrm{H}_{2} \mathrm{O} \rightarrow \mathrm{H}^{+}+\mathrm{HO}^{\bullet}$

$2 \mathrm{O}_{2}^{\bullet-}+2 \mathrm{H}_{2} \mathrm{O} \rightarrow \mathrm{H}_{2} \mathrm{O}_{2}+2 \mathrm{OH}^{-}+\mathrm{O}_{2}$

$\mathrm{H}_{2} \mathrm{O}_{2}+\mathrm{e}_{\mathrm{cb}}{ }^{-} \rightarrow \mathrm{OH}^{-}+\mathrm{HO}^{\bullet}$

Limitations effecting the broad application of $\mathrm{UV} \mathrm{TiO}_{2}$ photocatalysis include the requirement of costly UV light $(<387 \mathrm{~nm})$ and the rapid recombination of $\mathrm{e}_{\mathrm{cb}}{ }^{-} / \mathrm{h}_{\mathrm{vb}}{ }^{+}$pairs, leading to low quantum yields. The wavelengths of solar irradiation that reach the surface of the earth are mostly in the visible region (40\%) with a small fraction $(5 \%)$ in UV region. Hence, photocatalysts activated by visible light or by a broad spectrum of wavelengths (solar) have significant economic advantages. Doping of $\mathrm{TiO}_{2}\left(\mathrm{NF}-\mathrm{TiO}_{2}, \mathrm{PF}-\mathrm{TiO}_{2}\right.$ and $\mathrm{S}-\mathrm{TiO}_{2}$ ) can result in a decrease band gap such that longer wavelength light (visible and solar light) becomes applicable $[17,18]$. In addition, doped $\mathrm{TiO}_{2}$ can inhibit $\mathrm{e}_{\mathrm{cb}}{ }^{-} / \mathrm{h}_{\mathrm{vb}}{ }^{+}$pairs recombination through trapping of charge carriers. VLA photocatalysis employing $\mathrm{TiO}_{2}$ based materials has received significant attention recently and also been reviewed by the research groups of Zhao [19] and Dionysiou [20]. UV and $\mathrm{VLA} \mathrm{TiO}_{2}$ photocatalysis are effective for treatment of microcystin cyanotoxins (MC), however only a limited number of reports have appeared on the photocatalysis of CYN [21]. The high cost of CYN limited our ability to conduct detailed studies to optimize the reaction conditions for the $\mathrm{TiO}_{2}$ photocatalytic destruction of CYN. The uracil moiety in CYN is critical to the toxicity of CYN. HO• reacts primarily (84\%) at the uracil ring of CYN [22]. With this in mind, 6-hydroxymethyl uracil (6-HOMU) (Fig. 1) was synthesized and used as a model compound for the UV and VLA photocatalysis of CYN. We report herein the photocatalytic activity of different non-metal doped $\mathrm{TiO}_{2}$ materials, $\mathrm{NF}-\mathrm{TiO}_{2}, \mathrm{PF}-\mathrm{TiO}_{2}$

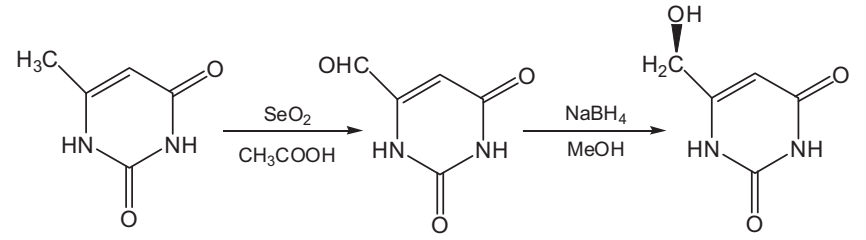

Fig. 2. Synthesis of 6-hydroxymethyl uracil.

and $\mathrm{S}_{-} \mathrm{TiO}_{2}$ under 350,420 and $450 \mathrm{~nm}$ irradiation. Among these photocatalysts, $\mathrm{NF}-\mathrm{TiO}_{2}$ was the most UV and visible light active for the degradation of the CYN model compound. The treatment is effective over a range of $\mathrm{pH}$, and in the presence of ions and $\mathrm{HA}$. $\mathrm{O}_{2}{ }^{\bullet-}$ appears to play the predominant role in the VLA photocatalytic degradation process. Our results demonstrate $\mathrm{NF}^{-\mathrm{TiO}_{2}}$ can be used for the UV and visible light photocatalytic destruction of uracil based compounds under a variety of conditions.

\section{Materials and methods}

\subsection{Materials}

$\mathrm{FeCl}_{3} \cdot 6 \mathrm{H}_{2} \mathrm{O}, \mathrm{CuCl}_{2} \cdot 2 \mathrm{H}_{2} \mathrm{O}, \mathrm{CaCl}_{2} \cdot 2 \mathrm{H}_{2} \mathrm{O}, \mathrm{MgCl}_{2}$ as the sources of common ions, acetic acid, sodium bisulfite and HPLC grade methanol were purchased from Fisher Scientific. The humic acid was obtained from Fluka. 6-Methyl uracil and selenium dioxide were purchased from Sigma Aldrich. Sodium borohydride was obtained from Acros organics. All reagents were used as received. The synthesis and characterization of the doped- $\mathrm{TiO}_{2}$ materials $\left(\mathrm{NF}-\mathrm{TiO}_{2}, \mathrm{PF}-\mathrm{TiO}_{2}\right.$, and $\left.\mathrm{S}-\mathrm{TiO}_{2}\right)$ are reported elsewhere $[17,18]$. The model compound (6-hydroxymethyl uracil) was synthesized according to standard organic functional group transformations. All aqueous solutions were prepared with Millipore filtered water.

\subsection{Sample preparation}

The loading of doped- $\mathrm{TiO}_{2}$ materials employed for UV photocatalysis experiments was $0.05 \mathrm{~g} / \mathrm{L}$ with the initial model compound concentration of $5 \mathrm{ppm}$ unless otherwise stated. VLA $\mathrm{TiO}_{2}$ photocatalysis of model compound was conducted with $0.1 \mathrm{~g} / \mathrm{L}$ $\mathrm{NF}^{-\mathrm{TiO}_{2}}$ and $1 \mathrm{ppm}$ initial concentration of model compound. The reaction solution was transferred to a pyrex cylindrical reactor ( $12 \times 1$ in., $150 \mathrm{~mL}$ capacity, with a vented Teflon screw top) and magnetically stirred in the dark and purged with oxygen for 15 min prior to irradiation and during irradiation. A Rayonet photochemical reactor (Southern New England Ultra Violet Company, www.rayonet.org, model RPR-100) was used for all experiments, equipped with a cooling fan and 15 phosphor-coated inter changeable lamps at $\lambda=350,420$ and $450 \mathrm{~nm}$. Aliquots $(1 \mathrm{~mL})$ were collected at given time intervals and filtered through a $0.45 \mu \mathrm{m}$ filter prior to high-performance liquid chromatography (HPLC) analysis.

\subsection{Preparation of model compound}

The synthesis of 6-HOMU includes two steps (Fig. 2): synthesis of orotaldehyde and reduction of orotaldehyde to 6-HOMU. The orotaldehyde was prepared by Kwang-Yuen's method [23]. Briefly, 6-methyl uracil $(2.54 \mathrm{~g})$ was refluxed in acetic acid $(60 \mathrm{~mL})$ with selenium dioxide $(2.66 \mathrm{~g})$ for $6 \mathrm{~h}$. The hot reaction mixture was filtered and the yellow filtrate collected and solvent evaporated. The crude orotaldehyde was then dissolved in hot water $(24 \mathrm{~mL})$ and $5 \%$ sodium bisulfite was added dropwise into the stirred mixture. The solution was boiled with active carbon for $10 \mathrm{~min}$ and then gravity filtered to remove the carbon. The filtrate was acidified to 
Table 1

Doped $\mathrm{TiO}_{2}$ band gaps and corresponding photoexcited wavelengths.

\begin{tabular}{lll}
\hline Doped $\mathrm{TiO}_{2}$ & Band-gap $(\mathrm{eV})$ & Wavelength $\lambda(\mathrm{nm})$ \\
\hline $\mathrm{S}-\mathrm{TiO}_{2}$ & $2.94[18]$ & 422 \\
$\mathrm{NF}-\mathrm{TiO}_{2}$ & $2.75[17]$ & 451 \\
$\mathrm{PF}^{-T i O}$ & 2.68 & 463 \\
\hline
\end{tabular}

pH 1 using concentrated $\mathrm{HCl}$. Upon cooling, pure orotaldehyde was obtained as a precipitate from the solution. A mixture of pure orotaldehyde $(0.14 \mathrm{~g})$ and sodium borohydride $(0.076 \mathrm{~g})$ was refluxed in $95 \%$ methanol for $4 \mathrm{~h}$. The resulting solution was filtered and the solvent was evaporated yielding the pure 6-HOMU with the purity of $98 \% .{ }^{1} \mathrm{H}$ NMR spectrum $\left(400 \mathrm{MHz}, \mathrm{D}_{2} \mathrm{O}\right): \delta 4.234\left(2 \mathrm{H}, \mathrm{s}, \mathrm{CH}_{2}\right)$, $5.679(1 \mathrm{H}, \mathrm{s}, \mathrm{H} 5) .{ }^{13} \mathrm{C}$ NMR $\left(400 \mathrm{MHz}, \mathrm{D}_{2} \mathrm{O}\right): \delta 62.18\left(\mathrm{CH}_{2}\right), 98.76$ (C5), 160.19 (C2), 167.86 (C6), 170.63 (C4). Mass spectrum (ESI): $\mathrm{m} / \mathrm{z} 141.1(\mathrm{M}-1)$.

\subsection{Analysis}

The concentration of the model compound was monitored by HPLC, Varian ProStar equipped with a ProStar 410 autosampler and a ProStar 335 photodiode array detector under the following conditions: a Luna RP C18 column ( $5 \mu \mathrm{m}, 250 \mathrm{~mm} \times 4.6 \mathrm{~mm})$; $30 \mu \mathrm{L}$ injection volume and $1 \mathrm{~mL} / \mathrm{min}$ flow rate; The mobile phase was consisted of a linear gradient starting at 5\% methanol, 95\% water increased to $30 \%$ methanol in $5 \mathrm{~min}$ and then held constant for an additional $5 \mathrm{~min}$; the detection wavelength was at $260 \mathrm{~nm}$.

\section{Results and discussion}

\section{1. $\mathrm{TiO}_{2}$ photocatalysis of 6-hydroxymethyl uracil}

$\mathrm{TiO}_{2}$ photocatalysis experiments were carried out with 6-HOMU under 350, 420 and $450 \mathrm{~nm}$ irradiation varying only the catalysts, NF-TiO $2, \mathrm{PF}-\mathrm{TiO}_{2}$ and $\mathrm{S}-\mathrm{TiO}_{2}$, to evaluate the relative photocatalytic activity of these non-metal doped $\mathrm{TiO}_{2}$ materials. The concentration of 6-HOMU was monitored by HPLC as a function of irradiation time (Fig. 3). Under UV irradiation ( $350 \mathrm{~nm})$, the degradation follows the order of $\mathrm{NF}-\mathrm{TiO}_{2}>\mathrm{PF}-\mathrm{TiO}_{2}>\mathrm{S}-\mathrm{TiO}_{2}$. The percent removal of $6-\mathrm{HOMU}$ was 100,86 and $59 \%$ for $\mathrm{NF}-\mathrm{TiO}_{2}, \mathrm{PF}-\mathrm{TiO}_{2}$ and $\mathrm{S}-\mathrm{TiO}_{2}$, respectively after $120 \mathrm{~min}$ of UV irradiation. The observed pseudofirst-order rate constants $(k)$ were $2.1 \mathrm{~h}^{-1}$ for $\mathrm{NF}^{-\mathrm{TiO}_{2}}, 1.0 \mathrm{~h}^{-1}$ for $\mathrm{PF}_{-\mathrm{TiO}_{2}}$, and $0.44 \mathrm{~h}^{-1}$ for $\mathrm{S}-\mathrm{TiO}_{2}$. VLA NF-TiO 2 photocatalysis (at 420 and $450 \mathrm{~nm}$ ) leads to the degradation of 6 -HOMU but at a slower rate than under UV irradiation (Fig. 3). 6-HOMU was slightly degraded by $\mathrm{PF}^{-} \mathrm{TiO}_{2}$ under $420 \mathrm{~nm}$ irradiation and no degradation was observed employing $\mathrm{S}^{-\mathrm{TiO}_{2}}$ under our VLA $(450 \mathrm{~nm})$ conditions. The photocatalytic activity of these materials is dependent on the recombination $\mathrm{e}_{\mathrm{cb}}{ }^{-} / \mathrm{h}_{\mathrm{vb}}{ }^{+}$pairs, the band gap energies and structural properties [17]. The band gaps of $\mathrm{NF}-\mathrm{TiO}_{2}, \mathrm{PF}-\mathrm{TiO}_{2}$ and $\mathrm{S}-\mathrm{TiO}_{2}$ and the corresponding photoexcitation wavelengths are presented in Table 1.

$\mathrm{PF}^{-\mathrm{TiO}_{2}}$ has the smallest band gap and should be activated by wavelengths of $\leq 463 \mathrm{~nm}$. However, no degradation was observed at $450 \mathrm{~nm}$ during VLA PF-TiO 2 under our conditions, indicating that $\mathrm{PF}^{-\mathrm{TiO}_{2}}$ has the poor photocatalytic activity likely due to faster recombination $\mathrm{e}_{\mathrm{cb}}{ }^{-} / \mathrm{h}_{\mathrm{vb}}{ }^{+}$pairs and poor structural properties. While the band gap energy of $\mathrm{S}^{-\mathrm{TiO}_{2}}(\sim 422 \mathrm{~nm})$ matches well with the light source of $420 \mathrm{~nm}$, no detectable degradation of 6HOMU was observed under $420 \mathrm{~nm}$ irradiation after $4 \mathrm{~h}$. VLA S- $\mathrm{TiO}_{2}$ photocatalysis was reported to be effective for the destruction of microcystin-LR (MC-LR) [18]. The differences in the structures
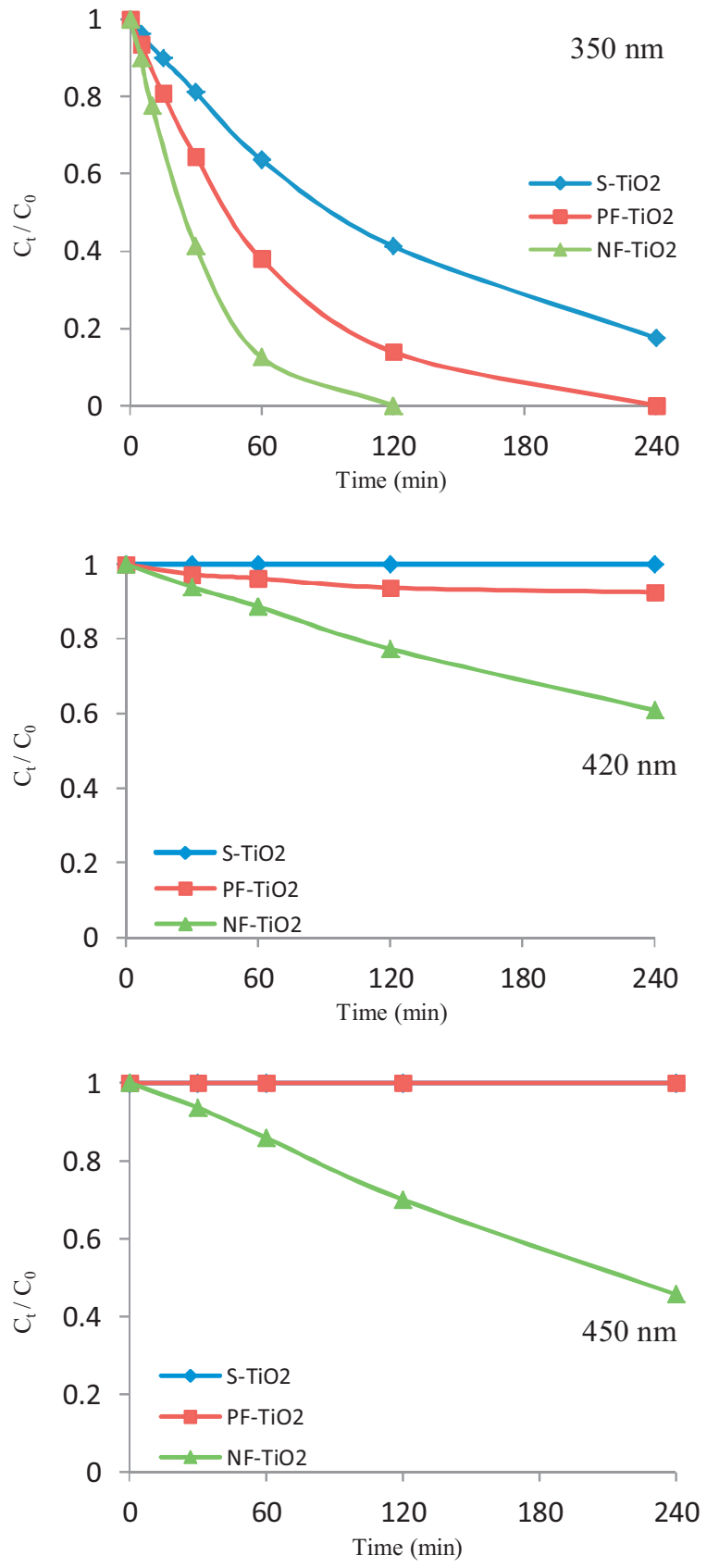

Fig. 3. $\mathrm{TiO}_{2}$ photocatalysis of 6-HOMU under 350,420 and $450 \mathrm{~nm}$. [6$\mathrm{HOMU}]_{0}=5 \mathrm{ppm},\left[\mathrm{TiO}_{2}\right]=0.05 \mathrm{~g} / \mathrm{L}$. The reproducibility is within $\pm 10 \%$ on the basis of triplicate runs.

of the MC-LR and 6-HOMU will influence the adsorption and hence degradation of these compounds. MC-LR has more functional groups (carboxylic acid, amide, amine) than 6-HOMU, which will enhance the adsorption and subsequent degradation of MC-LR by the surface initiated processes involved in heterogeneous photocatalysis. $\mathrm{NF}-\mathrm{TiO}_{2}$ leads to the effective degradation of 6-HOMU under UV and visible light irradiation indicating the recombination of $\mathrm{e}_{\mathrm{cb}}{ }^{-} / \mathrm{h}_{\mathrm{vb}}{ }^{+}$pairs in $\mathrm{NF}-\mathrm{TiO}_{2}$ with a band gap of $2.75 \mathrm{eV}$ is slow enough to allow the production of ROS [17]. VLA $\mathrm{TiO}_{2}$ photocatalysis using $\mathrm{NF}^{-\mathrm{TiO}_{2}}$ is reported to be effective for a number of compounds including acetic acid [24] and 4-chlorophenol [25]. Our results indicate that $\mathrm{NF}-\mathrm{TiO}_{2}$ should be an effective visible light driven photocatalyst for the destruction of the CYN. 
Table 2

Pseudo-first-order rate constants ( $k$ ) of 6-HOMU under 350, 420 and $450 \mathrm{~nm}$ irradiation.

\begin{tabular}{llll}
\hline Photocatalysts & \multicolumn{2}{l}{$k\left(\mathrm{~h}^{-1}\right)\left(R^{2}\right)$} & \\
\cline { 2 - 4 } & $350 \mathrm{~nm}$ & $420 \mathrm{~nm}$ & $450 \mathrm{~nm}$ \\
\hline $\mathrm{S}^{-\mathrm{TiO}_{2}}$ & $0.44(0.999)$ & $0.0(1.00)$ & $0.0(1.00)$ \\
$\mathrm{PF}^{\mathrm{TiO}}{ }_{2}$ & $1.0(0.999)$ & $0.03(0.915)$ & $0.0(1.00)$ \\
$\mathrm{NF}^{-\mathrm{TiO}_{2}}$ & $2.1(0.994)$ & $0.12(0.994)$ & $0.20(0.996)$ \\
\hline
\end{tabular}

\subsection{Degradation kinetics}

The $\mathrm{TiO}_{2}$ photocatalytic degradation kinetics of 6-HOMU were evaluated under 350, 420 and $450 \mathrm{~nm}$ irradiation for each catalyst. While $\mathrm{TiO}_{2}$ photocatalysis is a heterogeneous process, the initial degradation kinetics often follows pseudo-first-order type kinetics [26]. The concentration of 6-HOMU was monitored by HPLC as a function of irradiation time. The plots of $\ln \left(C_{0} / C\right)$ as a function of treatment time exhibit linear relationships and the pseudo-first order rate constants were determined from the slope of the line. The results are summarized in Table 2 .

\subsection{Heterogeneous kinetics}

Evaluation of reaction kinetics can provide useful mechanistic information and important parameters for the assessment and modeling $\mathrm{TiO}_{2}$ photocatalytic treatment. $\mathrm{TiO}_{2}$ photocatalysis involves the generation of ROS and their subsequent reactions with the adsorbed target compounds at the $\mathrm{TiO}_{2}$ surface. In these heterogeneous processes, both adsorption and reactivity play critical roles in governing the degradation. To assess the adsorption and reactivity parameters for heterogeneous $\mathrm{TiO}_{2}$ photocatalysis, the Langmuir-Hinshelwood (L-H) kinetic model was employed Eq. (6). The $\mathrm{L}-\mathrm{H}$ model has been widely used for assessment of $\mathrm{TiO}_{2}$ photocatalysis at the liquid-solid interfaces [26,27]. This model assumes limited surface adsorption sites, no interaction between adsorbed species on the surface and reversible adsorption reaction [28].

$\frac{1}{r_{0}}=\frac{1}{k_{r} K C_{0}}+\frac{1}{k_{r}}$

where $r_{0}$ is the initial rate, $C_{0}$ is the initial 6-HOMU concentration, $k_{r}$ is a reactivity coefficient related to oxidation reactions, and $K$ is the equilibrium constant related to surface adsorption. The L-H model applied to $\mathrm{TiO}_{2}$ photocatalysis yields apparent kinetic parameters. The L-H experiments were conducted over a range of initial concentrations (3.52-35.2 $\mu \mathrm{M})$ and a constant $\mathrm{NF}^{-\mathrm{TiO}_{2}}$ concentration $(0.1 \mathrm{~g} / \mathrm{L})$ under visible light $(450 \mathrm{~nm})$ irradiation (Fig. 4). The L-H kinetic parameters $k_{r}$ and $\mathrm{K}$ were determined from the slope and

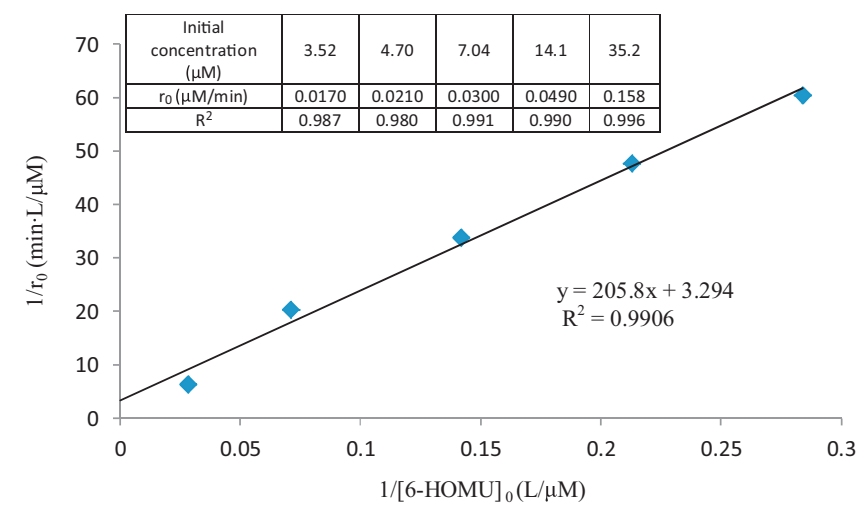

Fig. 4. $\mathrm{L}-\mathrm{H}$ plot of $\mathrm{TiO}_{2}$ photocatalysis of 6-HOMU under visible light $(450 \mathrm{~nm})$. The insert table is the initial rates at different concentration of 6-HOMU. [NF$\left.\mathrm{TiO}_{2}\right]=0.1 \mathrm{~g} / \mathrm{L}$. The reproducibility is within $\pm 5 \%$ on the basis of triplicate runs.

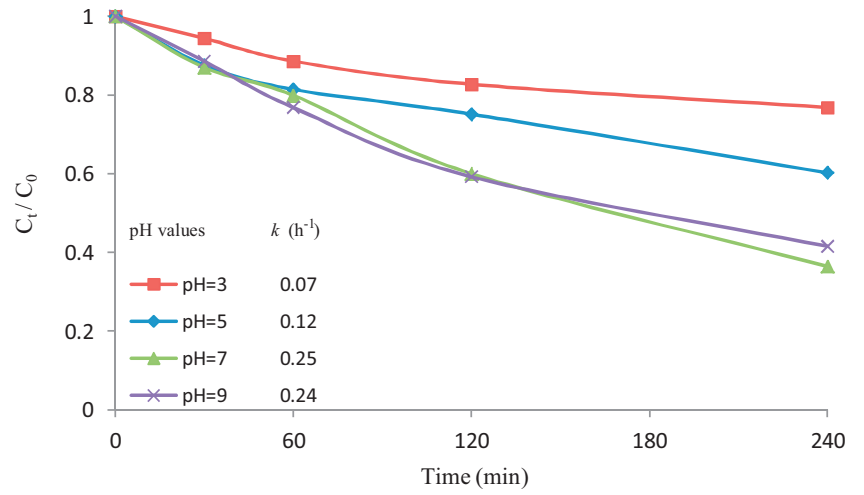

Fig. 5. $\mathrm{TiO}_{2}$ photocatalysis of $6-\mathrm{HOMU}$ at $\mathrm{pH} 3,5,7$ and 9 . The insert table is the 1 st order rate constants at different solution $\mathrm{pH} .[6-\mathrm{HOMU}]_{0}=1 \mathrm{ppm},\left[\mathrm{NF}-\mathrm{TiO}_{2}\right]=0.1 \mathrm{~g} / \mathrm{L}$, $\lambda=450 \mathrm{~nm}$. The reproducibility is within $\pm 5 \%$ on the basis of triplicate runs.

intercept of the linear fit of the $1 / r_{0}$ vs. $1 / C_{0}$, which shows that $k_{r}$ is $0.304 \mu \mathrm{M} / \mathrm{L}$ min and $K$ is $0.016 \mathrm{~L} / \mu \mathrm{M}$ under our experimental conditions. L-H kinetic parameters for phenylarsonic acid (PA) with P-25 $\mathrm{TiO}_{2}$ using the same reaction vessels and photochemical reactor under $350 \mathrm{~nm}$ irradiation has been reported with $k_{r} 2.8 \mu \mathrm{M} / \mathrm{L}$ min and $\mathrm{K} 0.034 \mathrm{~L} / \mu \mathrm{M}$ [29]. The $\mathrm{L}-\mathrm{H}$ parameters for $\mathrm{PA}$ under $\mathrm{UV} \mathrm{TiO}_{2}$ photocatalysis may imply stronger adsorption and a more reactive system than 6 -HOMU treatment by $\mathrm{VLA}$ NF- $\mathrm{TiO}_{2}$ photocatalysis. The degradations at different initial concentrations follow pseudofirst-order kinetic model (insert table in Fig. 4). The apparent kinetic parameters obtained from our results are useful for modeling and predicting specific treatment objectives.

\subsection{Environmental factors on $\mathrm{VLA} \mathrm{TiO}_{2}$ photocatalysis}

\subsection{1. $p H$ effects}

VLA $\mathrm{TiO}_{2}$ photocatalyses of 6-HOMU were performed under acidic, neutral, and basic conditions ( $\mathrm{pH} \mathrm{3,5,7}$ and 9). The concentrations of 6-HOMU as a function of irradiation time at different $\mathrm{pH}$ values are illustrated in Fig. 5. The degradation of 6-HOMU was fastest at $\mathrm{pH} 7$ and 9 with overall degradation of $62 \pm 3 \%$, decreasing to $40 \%$ at $\mathrm{pH} 5$ and to $23 \%$ at $\mathrm{pH} 3$ after $4 \mathrm{~h}$ of treatment. The decrease in degradation with decreasing $\mathrm{pH}$ is rationalized based on electrostatic repulsion between positively charged 6-HOMU and the $\mathrm{NF}^{-\mathrm{TiO}_{2}}$ surface. The point of zero charge (PZC) for $\mathrm{NF}-\mathrm{TiO}_{2}$ is 6.4 [17]. Under acidic conditions, the surface of $\mathrm{NF}^{-\mathrm{TiO}_{2}}$ is protonated $\left(\mathrm{TiO}_{2} \mathrm{H}^{+}\right)$and possesses an overall positive charge. While the $\mathrm{p} K_{\mathrm{a}}$ value for 6-HOMU is not reported, we assume the $\mathrm{p} K_{\mathrm{a}}$ of 6 HOMU is similar to 5-HOMU $\left(\mathrm{p} K_{\mathrm{a}}=9.27\right)$ [30] and thus positively charged in the $\mathrm{pH}$ range of this study. The neutral and negative charges on the surface of the catalyst under neutral and basic conditions lead to stronger adsorption of the positively charged 6-HOMU and thus faster degradation. As the $\mathrm{pH}$ decreases the overall positive charge on the surface increases along with the electrostatic repulsion with positively charged 6-HOMU inhibiting adsorption resulting in slower degradation at under acidic conditions.

\subsubsection{Dissolved metal ions effects}

Dissolved ions can influence the overall efficiency of $\mathrm{TiO}_{2}$ photocatalysis of organic compounds. In order to investigate the influence of dissolved ions on $\mathrm{VLA} \mathrm{TiO} 2$ photocatalysis, $\mathrm{Ca}^{2+}, \mathrm{Mg}^{2+}$, $\mathrm{Fe}^{3+}$ and $\mathrm{Cu}^{2+}$ ions were added to the reaction solutions in the range of $0.2-8 \mathrm{ppm}$. The effects of $\mathrm{Ca}^{2+}$ and $\mathrm{Mg}^{2+}$ ions on photocatalysis of 6-HOMU are negligible under our experimental conditions. The pseudo-first-order rate constants $(k)$ of 6-HOMU photodegradation with $\mathrm{Ca}^{2+}, \mathrm{Mg}^{2+}$ and without the ions are identical $\left(0.25 \pm 0.01 \mathrm{~h}^{-1}\right)$. The addition of $\mathrm{Fe}^{3+}$ and $\mathrm{Cu}^{2+}$ ions enhanced the VLA $\mathrm{TiO}_{2}$ 


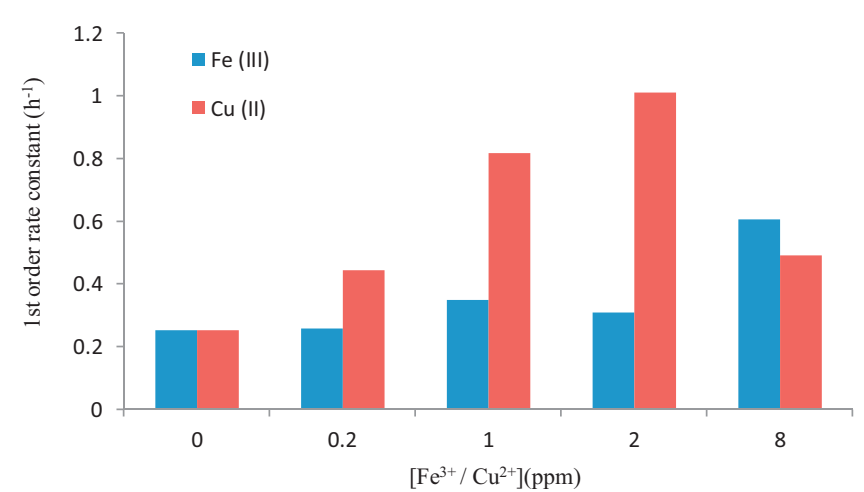

Fig. 6. The effects of $\mathrm{Fe}^{3+}$ and $\mathrm{Cu}^{2+}$ ion on $\mathrm{TiO}_{2}$ photocatalysis of 6-HOMU. [6$\mathrm{HOMU}]_{0}=1 \mathrm{ppm},\left[\mathrm{NF}-\mathrm{TiO}_{2}\right]=0.1 \mathrm{~g} / \mathrm{L}, \lambda=450 \mathrm{~nm}$. The reproducibility is within $\pm 2 \%$ on the basis of triplicate runs.

photocatalysis of 6-HOMU. In the presence of $\mathrm{Fe}^{3+}$ ions, the degradation rate constant increased by $\sim 2.5$ times at a concentration of $8 \mathrm{ppm}$ with pseudo-first-order rate constant $(k)$ of $0.61 \mathrm{~h}^{-1}$. The $\mathrm{NF}^{-\mathrm{TiO}_{2}}$ photocatalysis process of 6 -HOMU was also promoted by adding $\mathrm{Cu}^{2+}$ ions in the range of $0.2-2 \mathrm{ppm}$. The presence of $\mathrm{Fe}^{3+} / \mathrm{Fe}^{2+}$ and $\mathrm{Cu}^{2+}$ ions can promote photo-Fenton/Fenton type reactions Eqs. (7) and (8) to produce $\mathrm{HO}^{\bullet}$ which may be responsible for the observed enhancement in the degradation of 6-HOMU.

$\mathrm{Fe}^{3+} / \mathrm{Cu}^{2+}+\mathrm{e}^{-} \rightarrow \mathrm{Fe}^{2+} / \mathrm{Cu}^{+}$

$\mathrm{Fe}^{2+} / \mathrm{Cu}^{+}+\mathrm{H}_{2} \mathrm{O}_{2} \rightarrow \mathrm{Fe}^{3+} / \mathrm{Cu}^{2+}+\mathrm{HO}^{\bullet}+\mathrm{HO}^{-}$

$\mathrm{Fe}^{3+} / \mathrm{Cu}^{2+}$ ions can also scavenge the $\mathrm{e}_{\mathrm{cb}}{ }^{-}$during $\mathrm{TiO}_{2}$ photocatalysis, converting to $\mathrm{Fe}^{2+} / \mathrm{Cu}^{+}$ions, while inhibiting $\mathrm{e}_{\mathrm{cb}}{ }^{-} / \mathrm{h}_{\mathrm{vb}}{ }^{+}$ pairs recombination to indirectly increase the $\mathrm{HO}^{\bullet}$ production. The decrease in the degradation rate constant at higher $\mathrm{Cu}^{2+}$ ion concentrations may be the result of $\mathrm{Cu}^{2+}$ ions acting as the primary $\mathrm{e}_{\mathrm{cb}}{ }^{-}$ scavenger at the expense of dissolve oxygen, inhibiting the formation of $\mathrm{O}_{2}{ }^{\bullet-}$ and thus reducing the levels of $\mathrm{O}_{2}{ }^{--}$and indirectly reducing the production of $\mathrm{HO}^{\bullet}$. Under our experimental conditions, inhibition however was not observed in the case of $\mathrm{Fe}^{3+}$ which may be a result of stronger adsorption of $\mathrm{Cu}^{2+}$ at the $\mathrm{TiO}_{2}$ surface leading to more effective competition for $\mathrm{e}_{\mathrm{cb}}{ }^{-}$(Fig. 6).

\subsubsection{Dissolved organic matter (DOM) effects}

The presence of dissolved organic matter (DOM) can have a pronounced effect on photochemical based water treatment processes. DOM derived from decomposed biomass is composed of large carbon based structures with a number of light absorbing chromophores. Upon light absorption DOM can lead to an excited state $\left(\mathrm{DOM}^{*}\right)$ Eq. (9). The DOM* can undergo energy or electron transfer pathways with molecular oxygen to generate ${ }^{1} \mathrm{O}_{2}$ or $\mathrm{O}_{2}{ }^{\bullet-}$ Eq. (10). These ROS can initiate the degradation of 6-HOMU, Eq. (11). The $\mathrm{DOM}^{*}$ can also sensitize $\mathrm{TiO}_{2}$ Eq. (12) leading to charge carriers with the potential to initiate degradation processes Eq. (13).

$\mathrm{DOM}+\mathrm{h} v \rightarrow \mathrm{DOM} *$

$\mathrm{DOM} *+\mathrm{O}_{2} \rightarrow{ }^{1} \mathrm{O}_{2}\left(\mathrm{O}_{2}{ }^{\bullet-}\right)$

${ }^{1} \mathrm{O}_{2}\left(\mathrm{O}_{2}^{\bullet-}\right)+6-\mathrm{HOMU} \rightarrow 6-\mathrm{HOMU}_{[\mathrm{OX}]}$

$\mathrm{DOM} *+\mathrm{TiO}_{2} \rightarrow \mathrm{TiO}_{2} *$

$\mathrm{TiO}_{2} * \rightarrow \mathrm{e}_{\mathrm{cb}}{ }^{-}+\mathrm{h}_{\mathrm{vb}}{ }^{+} \rightarrow \mathrm{ROS}+6-\mathrm{HOMU} \rightarrow 6-\mathrm{HOMU}_{[\mathrm{OX}]}$

The influence of DOM on the solar photolysis of organic contaminants has been widely studied [31,32]. We used HA to assess the role of DOM* initiated degradation of 6 -HOMU under $450 \mathrm{~nm}$

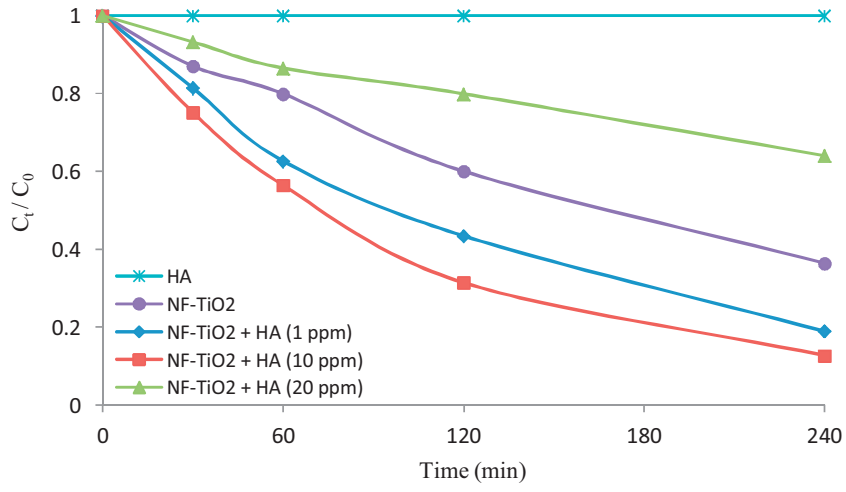

Fig. 7. The effects of $\mathrm{HA}$ on photo-transformation and $\mathrm{TiO}_{2}$ photocatalysis of 6 HOMU. $[6-\mathrm{HOMU}]_{0}=1 \mathrm{ppm},\left[\mathrm{NF}-\mathrm{TiO}_{2}\right]=0.1 \mathrm{~g} / \mathrm{L}, \lambda=450 \mathrm{~nm}$. The reproducibility is within $\pm 5 \%$ on the basis of triplicate runs.

irradiation in the absence of $\mathrm{NF}-\mathrm{TiO}_{2}$ as a control experiment. The photolysis of 6-HOMU was also carried out in the presence of HA under $450 \mathrm{~nm}$ irradiation for $240 \mathrm{~min}$. The concentration of 6-HOMU was monitored as a function irradiation time under different experimental conditions, shown in (Fig. 7). DOM alone did not lead to the photo-transformation 6-HOMU under our experimental conditions.

The concentrations of HA were varied from 1 to $20 \mathrm{ppm}$ while holding the catalyst loading and 6-HOMU constant. The observed degradation of 6-HOMU in the absence and presence of different HA concentrations are illustrated in Fig. 7. An enhanced degradation was observed for HA concentrations between 1 and $10 \mathrm{ppm}$. This enhancement was attributed to HA photosensitized processes, in which ROS can be formed to accelerate the overall photodegradation. However, the degradation process was strongly inhibited by the increased HA because at higher concentrations, HA can act as a light filter and attenuate the photochemically active processes [33], as well as scavenge ROS leading to the reduced degradation of 6-HOMU.

\subsection{The role of reactive oxygen species in $\mathrm{VLATiO}$, photocatalysis}

$\mathrm{UV} \mathrm{TiO}_{2}$ photocatalysis leads to a number of ROS, among them $\mathrm{HO}$ • produced by $\mathrm{h}_{\mathrm{vb}}{ }^{+}$oxidation of adsorbed hydroxyl groups is generally considered responsible for the degradation of organic pollutants and toxins. While the effectiveness of $\mathrm{UV} \mathrm{TiO}_{2}$ photocatalysis is often correlated to the production of $\mathrm{HO}^{\bullet}$, during VLA doped- $\mathrm{TiO}_{2}$ photocatalysis the direct formation of $\mathrm{HO}{ }^{\bullet}$ from $\mathrm{h}_{\mathrm{vb}}{ }^{+}$is not thermodynamically plausible. VLA doped- $\mathrm{TiO}_{2}$ photocatalysis can however lead to the formation of $\mathrm{HO}^{\bullet}$ indirectly from $\mathrm{O}_{2}{ }^{\bullet-}$. $\mathrm{O}_{2}{ }^{\bullet-}$ can also lose an electron to produce ${ }^{1} \mathrm{O}_{2}$ which can contribute to the oxidation of organic compounds. In an attempt to better understand the formation and roles of different ROS during VLA NF- $\mathrm{TiO}_{2}$ photocatalysis, specific scavengers were employed during the treatment of 6-HOMU. The degradation of 6-HOMU was carried out in the absence and presence of various quenchers and scavengers as outlined in Table 3. Molecular oxygen was used as the $\mathrm{e}_{\mathrm{cb}}{ }^{-}$scavenger, $t$-BuOH was added as a $\mathrm{HO} \bullet$ scavenger, furfuryl alcohol was used to probe the role of ${ }^{1} \mathrm{O}_{2}$, formic acid was used to quench oxidative processes, and superoxide dismutase employed to quench $\mathrm{O}_{2}{ }^{\bullet-}$.

The results of the quenching experiments are summarized in Fig. 8. In the absence of dissolved oxygen (Argon saturated conditions) no detectable degradation of 6-HOMU was observed during VLA NF-TiO 2 photocatalysis illustrating molecular oxygen is required for the degradation as an $\mathrm{e}_{\mathrm{cb}}{ }^{-}$trap and/or in the production of $\mathrm{O}_{2}{ }^{\bullet-}$. The presence of $t-\mathrm{BuOH}$, a $\mathrm{HO} \bullet$ scavenger, significantly reduced the observed degradation of 6-HOMU. While hydroxyl 
Table 3

Scavengers effects on $\mathrm{TiO}_{2}$ photodegradation.

\begin{tabular}{|c|c|c|}
\hline Reactive species & Scavengers & Mechanisms \\
\hline $\mathrm{e}_{\mathrm{cb}}{ }^{-}$(electron) & $\mathrm{O}_{2}$ & $\begin{array}{l}\mathrm{e}_{\mathrm{cb}}^{-}+\mathrm{O}_{2} \rightarrow \mathrm{O}_{2}^{\bullet-} \\
k=7.6 \times 10^{7} \mathrm{M}^{-1} \mathrm{~s}^{-1}[34]\end{array}$ \\
\hline HO• (hydroxyl radical) & $t$-BuOH (tert-Butyl alcohol) & $\begin{array}{l}\mathrm{HO} \cdot+t- \\
\mathrm{BuOH} \rightarrow \mathrm{H}_{2} \mathrm{O}+\cdot \mathrm{CH}_{2} \mathrm{C}\left(\mathrm{CH}_{3}\right)_{2} \mathrm{OH} \\
k=5.0 \times 10^{8} \mathrm{M}^{-1} \mathrm{~s}^{-1}[34]\end{array}$ \\
\hline${ }^{1} \mathrm{O}_{2}$ (singlet oxygen) & Furfuryl alcohol (FFA) & $\begin{array}{l}\mathrm{FFA}+{ }^{1} \mathrm{O}_{2} \rightarrow \mathrm{FFA}_{\mathrm{ox}} \\
k=1.2 \times 10^{8} \mathrm{M}^{-1} \mathrm{~s}^{-1}\end{array}$ \\
\hline $\mathrm{h}_{\mathrm{vb}}{ }^{+}$(hole) & $\mathrm{HCO}_{2} \mathrm{H}$ (formic acid) & $2 \mathrm{~h}_{\mathrm{vb}}^{+}+2 \mathrm{HCO}_{2}^{-} \rightarrow \mathrm{CO}_{2}+2 \mathrm{H}^{+}$ \\
\hline $\mathrm{O}_{2} \cdot-($ superoxide anion radical) & SOD $_{\text {red }}$ (superoxide dismutase) & $\begin{array}{l}\mathrm{SOD}_{\text {red }}+\mathrm{O}_{2} \cdot-+2 \mathrm{H}^{+} \rightarrow \mathrm{SOD}+\mathrm{H}_{2} \mathrm{O}_{2} \\
k=2.0 \times 10^{9} \mathrm{M}^{-1} \mathrm{~s}^{-1}[34]\end{array}$ \\
\hline
\end{tabular}

radicals do not form directly via the $\mathrm{h}_{\mathrm{vb}}{ }^{+}$oxidation of surface hydroxyl groups during $\mathrm{VLA} \mathrm{NF-TiO} 2$ photocatalysis, the formation of $\mathrm{HO}^{\bullet}$ can occur indirectly via reduction of $\mathrm{H}_{2} \mathrm{O}_{2}$ the product of $\mathrm{O}_{2}{ }^{\bullet-}$ disproportion.

Furfuryl alcohol (FFA) is commonly used as a scavenger for ${ }^{1} \mathrm{O}_{2}$, but also readily reacts with $\mathrm{HO}^{\bullet}[36]$ and thus can function as a scavenger for both ${ }^{1} \mathrm{O}_{2}$ and $\mathrm{HO}^{\bullet}$. The decreases in degradation of 6HOMU were similar in the presence of FFA and $t-\mathrm{BuOH}$, a selective $\mathrm{HO} \bullet$ scavenger. Since FFA quenches ${ }^{1} \mathrm{O}_{2}$ and $t$ - $\mathrm{BuOH}$ does not, the similar decrease in the presence of FFA or $t$-BuOH indicates ${ }^{1} \mathrm{O}_{2}$ plays a minimal role in the degradation process. To further test the role of ${ }^{1} \mathrm{O}_{2}$ in VLA NF- $\mathrm{TiO}_{2}$ photocatalysis, the degradation of 6HOMU was performed in $\mathrm{D}_{2} \mathrm{O}$. The lifetime of ${ }^{1} \mathrm{O}_{2}$ in $\mathrm{D}_{2} \mathrm{O}$ is longer than that in $\mathrm{H}_{2} \mathrm{O}$ and thus singlet oxygen mediated processes are enhanced in $\mathrm{D}_{2} \mathrm{O}$. The degradations in solution of $\mathrm{H}_{2} \mathrm{O}$ and $\mathrm{D}_{2} \mathrm{O}$ were similar indicating ${ }^{1} \mathrm{O}_{2}$ does not play an important role under our experimental conditions.

VLA NF-TiO 2 photocatalysis of 6-HOMU was not affected by the presence of formic acid. While formic acid has been used to quench the $\mathrm{h}_{\mathrm{vb}}{ }^{+}$mediated processes during $\mathrm{UV} \mathrm{TiO} 2$ photocatalysis, our observations are consistent with previous reports that $\mathrm{h}_{\mathrm{vb}}{ }^{+}$trapped in the region of inter-valence band does not possess the redox potential to efficiently oxidize formic acid [37]. Therefore,

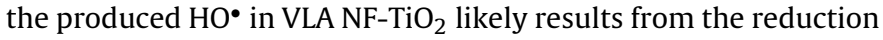
of $\mathrm{H}_{2} \mathrm{O}_{2}$ rather than oxidizing surface absorbed $\mathrm{H}_{2} \mathrm{O}$ by $\mathrm{h}_{\mathrm{vb}}{ }^{+}$. Our results indicate the photogenerated $\mathrm{h}_{\mathrm{vb}}{ }^{+}$in $\mathrm{VLANF}-\mathrm{TiO}_{2}$ photocatalysis does not play a significant role in the observed degradation process.

In $\mathrm{TiO}_{2}$ photocatalysis, dissolved oxygen serves as an electron trap and leads to the formation of $\mathrm{O}_{2}{ }^{\bullet-}$ which can proportionate or produce to ${ }^{1} \mathrm{O}_{2}$ with loss of an electron. In the presence of superoxide dismutase, an effective quencher of $\mathrm{O}_{2}{ }^{--}$, the degradation of 6 -HOMU was completely inhibited indicating that $\mathrm{O}_{2}{ }^{--}$is critical

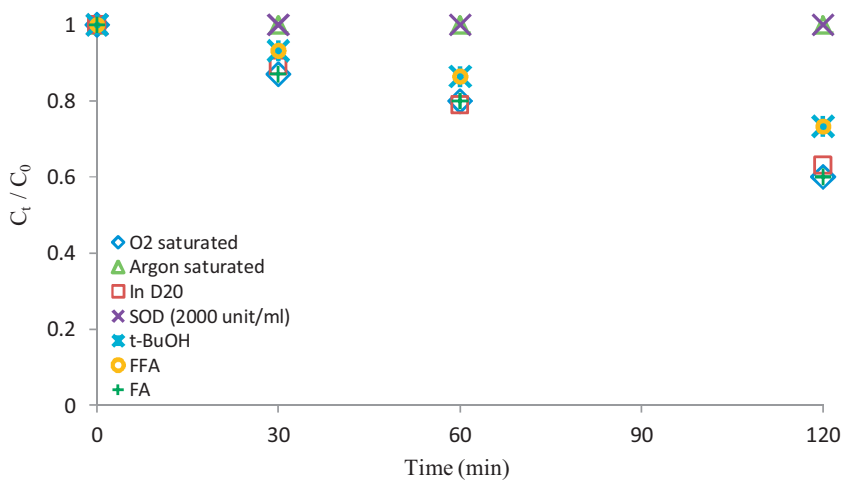

Fig. 8. The contribution of ROS to $\mathrm{VLATiO}_{2}$ photocatalysis. $[6-\mathrm{HOMU}]_{0}=1 \mathrm{ppm}$, $[\mathrm{NF}-$ $\left.\mathrm{TiO}_{2}\right]=0.1 \mathrm{~g} / \mathrm{L}, \lambda=450 \mathrm{~nm}$. The reproducibility is within $\pm 5 \%$ on the basis of triplicate runs. in the VLA NF-TiO 2 photocatalytic degradation process. $\mathrm{O}_{2}{ }^{\bullet-}$ has been implicated in the destruction of a strongly visible light absorbing dye during $\mathrm{VLA} \mathrm{TiO}_{2}$ photocatalysis [38]. The previous study is complicated by potential self-sensitized degradation pathways. Our model compound does not absorb visible-light and thus contributions from self-sensitized reaction pathways can be ruled out. Therefore, according to these findings, $\mathrm{O}_{2}{ }^{\bullet-}$ plays a critical role in $\mathrm{VLA} \mathrm{TiO}_{2}$ photocatalytic processes.

\section{Conclusions}

S- $\mathrm{TiO}_{2}, \mathrm{PF}-\mathrm{TiO}_{2}$ and $\mathrm{NF}-\mathrm{TiO}_{2}$ are photoactive under UV irradiation and the degradation of 6-HOMU follows a pseudo-first-order kinetic model. Among non-metal doped $\mathrm{TiO}_{2}$ materials, our results indicate that $\mathrm{NF}^{-\mathrm{TiO}_{2}}$ exhibits the best performance to destroy the model compound of CYN due to its high photocatalytic activity. The kinetics is accurately modeled and degradation is effective over a range of $\mathrm{pH}$. A synergetic effect is observed in photodegradation of 6-HOMU in the presence of $\mathrm{Fe}^{3+}, \mathrm{Cu}^{2+}$ ions and HA due to more production of $\mathrm{HO}^{\bullet}$ or ROS in the photooxidation process. Experiments performed in the presence of scavengers for $\mathrm{O}_{2}{ }^{\bullet-},{ }^{1} \mathrm{O}_{2}, \mathrm{HO}$ and $\mathrm{h}_{\mathrm{vb}}{ }^{+}$indicate that $\mathrm{O}_{2}{ }^{\bullet-}$ is the predominant species leading to the VLA $\mathrm{TiO}_{2}$ photocatalytic destruction of 6-HOMU. Our results provide a better fundamental understanding of the different roles of ROS during $\mathrm{VLA} \mathrm{TiO}_{2}$ photocatalysis and demonstrate $\mathrm{VLA} \mathrm{TiO}_{2}$ photocatalysis has potential for water treatment for cyanotoxins.

\section{Acknowledgement}

D.D.D. and K.E.O gratefully acknowledge support from the National Science Foundation (CBET, award 1033317).

\section{References}

[1] G.A. Codd, Water Sci. Technol. 32 (1995) 149-156.

[2] L. Ho, T. Meyn, A. Keegan, D. Hoefel, J. Brookes, C.P. Saint, G. Newcombe, Water Res. 40 (2006) 768-774.

[3] A.R. Humpage, M. Fenech, P. Thomas, I.R. Falconer, Mutat. Res. Genet. Toxicol. Environ. Mutagen. 472 (2000) 155-161.

[4] A.R. Humpage, F. Fontaine, S. Froscio, P. Burcham, I.R. Falconer, J. Toxicol. Environ. Health A 68 (2005) 739-753.

[5] I.R. Falconer, A.R. Humpage, Environ. Toxicol. 16 (2001) 192-195

[6] D.J. Griffiths, M.L. Saker, Environ. Toxicol. 18 (2003) 78-93.

[7] I. Ohtani, R.E. Moore, M.T.C. Runnegar, J. Am. Chem. Soc. 114 (1992) 7941-7942.

[8] M.L. Saker, A.D. Thomas, J.H. Norton, Environ. Toxicol. 14 (1999) 179-182.

[9] C.W.K. Chow, M. Drikas, J. House, M.D. Burch, R.M.A. Velzeboer, Water Res. 33 (1999) 3253-3262.

[10] G. Newcombe, B. Nicholson, J. Water Supply: Res. Technol. - AQUA 53 (2004) $227-239$.

[11] G. Newcombe, J. Morrison, C. Hepplewhite, D.R.U. Knappe, Carbon 40 (2002) 2147-2156.

[12] E. Rodriguez, A. Sordo, J.S. Metcalf, J.L. Acero, Water Res. 41 (2007) 2048-2056

[13] E. Rodriguez, G.D. Onstad, T.P.J. Kull, J.S. Metcalf, J.L. Acero, U. von Gunten, Water Res. 41 (2007) 3381-3393. 
[14] R.S. Thakur, R. Chaudhary, C. Singh, J. Renew. Sustain. Energy 2 (2010), 042701/1-042701/37.

[15] R. Thiruvenkatachari, S. Vigneswaran, I.S. Moon, Korean J. Chem. Eng. 25 (2008) 64-72.

[16] A.Y.C. Tong, R. Braund, D.S. Warren, B.M. Peake, Central Eur. J. Chem. 10 (2012) 989-1027.

[17] M. Pelaez, A.M. de la Cruz, E. Stathatos, P. Falaras, D.D. Dionysiou, Catal. Today 144 (2009) 19-25.

[18] C. Han, M. Pelaez, V. Likodimos, A.G. Kontos, P. Falaras, K. O’Shea, D.D. Dionysiou, Appl. Catal. B 107 (2011) 77-87.

[19] J. Zhao, C. Chen, W. Ma, Top. Catal. 35 (2005) 269-278.

[20] M. Pelaez, N.T. Nolan, S.C. Pillai, M.K. Seery, P. Falaras, A.G. Kontos, P.S.M. Dunlop, J.W.J. Hamilton, J.A. Byrne, K. O’Shea, M.H. Entezari, D.D. Dionysiou, Appl. Catal. B 125 (2012) 331-349.

[21] M. Pelaez, P. Falaras, A.G. Kontos, A.M. de la Cruz, K. O'Shea, P.S.M. Dunlop, J.A. Byrne, D.D. Dionysiou, Appl. Catal. B 121-122 (2012) 30-39.

[22] W. Song, S. Yan, W.J. Cooper, D.D. Dionysiou, K.E. O'Shea, Environ. Sci. Technol. 46 (2012) 12608-12615.

[23] K.-Y. Zee-Cheng, C.-C. Cheng, J. Heterocycl. Chem. 4 (1967) 163-165.

[24] G. Wu, J. Wen, S. Nigro, A. Chen, Nanotechnology 21 (2010), 085701/1-085701/6.
[25] X. Li, H. Zhang, X. Zheng, Z. Yin, L. Wei, J. Environ. Sci. (China) 23 (2011) 1919-1924.

[26] T. Xu, Y. Cai, K.E. O’Shea, Environ. Sci. Technol. 41 (2007) 5471-5477.

[27] D.F. Ollis, J. Phys. Chem. B 109 (2005) 2439-2444.

[28] M.A. Fox, M.T. Dulay, Heterogeneous photocatalysis, Chem. Rev. 93 (1993) $341-357$.

[29] S. Zheng, Y. Cai, K.E. O’Shea, J. Photochem. Photobiol. A 210 (2010) 61-68.

[30] E.J. Privat, L.C. Sowers, Mutat. Res. Fundam. Mol. Mech. Mutagen. 354 (1996) $151-156$.

[31] J.J. Guerard, Y.-P. Chin, H. Mash, C.M. Hadad, Environ. Sci. Technol. 43 (2009) $8587-8592$.

[32] Y. Chen, C. Hu, X. Hu, J. Qu, Environ. Sci. Technol. 43 (2009) 2760-2765.

[33] S. Canonica, U. von Gunten, J. Wenk, Environ. Sci. Technol. 45 (2011) 7947-7948.

[34] Z. Xu, C. Jing, F. Li, X. Meng, Environ. Sci. Technol. 42 (2008) 2349-2354.

[35] W.R. Haag, J. Hoigne, E. Gassman, A.M. Braun, Chemosphere 13 (1984) 631-640.

[36] A. Albinet, C. Minero, D. Vione, Sci. Total Environ. 408 (2010) 3367-3373.

[37] R. Beranek, B. Neumann, S. Sakthivel, M. Janczarek, T. Dittrich, H. Tributsch, H. Kisch, Chem. Phys. 339 (2007) 11-19.

[38] M. Stylidi, D.I. Kondarides, X.E. Verykios, Appl. Catal. B 47 (2004) 189-201. 